Tamara Vukić, doktorand ${ }^{1}$

Original scientific paper

Univerzitet u Nišu

UDC: 37.012

Filozofski fakultet

DOI: $10.5937 /$ istrped2001093V

Departman za pedagogiju

\title{
OBRAZOVANJE ZA ODRŽIVI RAZVOJ KAO IZBORNI PROGRAM
}

\begin{abstract}
Rezime: $U$ fokusu rada su stavovi nastavnika gimnazija o izbornom programu Obrazovanje za održivi razvoj. Polazeći od pretpostavke da nastavnici nemaju razvijenu svest o potrebi i značaju ovog izbornog programa, kao i da ovaj program posmatraju kao dodatno opterećenje za nastavni plan i program, sprovedeno je pilot istraživanje zasnovano na deskriptivnoj metodi i tehnici skaliranja. $U$ istraživanju je učestvovalo 173 nastavnika iz gimnazija u Nišu, Prokuplju, Knjaževcu i Boru. Data pretpostavka je delimično potvrđena $\mathrm{s}$ obzirom na to da nastavnici ne pokazuju eksplicitno jasan stav o tome da li izborni program predstavlja dodatno opterećenje za nastavni plan i program, a mišljenja su podeljena i u vezi sa: percepcijom realizacije izbornog programa kao dodatnog opterećenja za samog nastavnika; posedovanjem adekvatnih znanja i veština za njegovu realizaciju; stavom o potrebi da dati predmet bude na listi izbornih programa; mogućnostima da se putem izbornog programa utiče na svest i ponašanje učenika u oblasti održivog razvoja; potrebom da se obrazovanje za održivi razvoj kao predmet izučava u osnovnoj školi; interesovanjem učenika za pohađanje izbornog programa. Opšti zaključak je da nastavnicima nije poznata sama problematika održivog razvoja, te da korene negativnih i neodlučnih stavova u vezi sa izbornim programom treba tražiti u znanjima i stavovima nastavnika o samom konceptu održivog razvoja. S obzirom na to da su nastavnici identifikovani kao nosioci obrazovanja za održivi razvoj, ključ obrazovanja učenika za održivi razvoj jeste u obrazovanju i kontinuiranom usavršavanju nastavnika u ovoj oblasti.
\end{abstract}

Ključne reči: gimnazije, izborni program, nastavnici, obrazovanje za održivi razvoj.

\section{Uvod}

Kako je obrazovanje neizostavni deo razvoja i funkcionisanja savremenog čoveka, održivi razvoj kao aktuelnost i težnja savremenog društva, postao je sastavni deo obrazovanja, te se tako govori o obrazovanju za održivi razvoj, odnosno o obrazovanju čiji je zadatak da pripremi čoveka za život i rad u promenljivom okruženju, menjajući njegove stavove i podižući svest o globalnim problemima u sferi ekonomije, društva i životne sredine.

Polazeći od međunarodnih preporuka, održivi razvoj postao je sastavni deo kurikuluma na svim nivoima obrazovanja. U skladu sa time, sadržaji postojećih predmeta počeli da se posmatraju iz perspektive održivog razvoja, a kreirani su i novi predmeti čiji su sadržaji usko fokusirani na održivi razvoj. Tako se, i pored toga što se učenici u srednjem (opštem i stručnom) obrazovanju u Srbiji sa pojmom i problemima održivog razvoja susreću u okviru predmeta kao što su hemija, biologija, geografija i dr., u kurikulumima srednjih stručnih škola

'tamaravukic93@gmail.com 
mogu naći i predmeti posebno posvećeni održivom razvoju, shodno području obrazovanja, odnosno obrazovnom profilu. Odnedavno i opšte obrazovanje, gimnazije, nude izborni program Obrazovanje za održivi razvoj, koji svojim sadržajima postepeno upoznaje učenike sa dimenzijom zaštite životne sredine, a potom i sa nekim aspektima ekonomske i društvene dimenzije održivog razvoja.

U radu je predstavljen pojam obrazovanja za održivi razvoj, međunarodne i nacionalne strategije i dr. dokumenta koja naglasak stavljaju na potrebu za integracijom održivog razvoja u kurikulume; ukratko su i predstavljeni didaktičko-metodički aspekti realizacije izbornog programa Obrazovanje za održivi razvoj. Pored toga, ispitani su stavovi nastavnika gimnazija u vezi sa datim izbornim programom: da li je ovaj izborni program opterećenje za nastavni plan i program i same nastavnike, da li su za njegovu realizaciju potrebni posebno obučeni nastavnici, kako nastavnici percipiraju ličnu kompetentnost za realizaciju izbornog programa i sl. Nastavnici su nosioci obrazovanja za održivi razvoj, model i uzor ponašanja koji učenici slede i neko sa kime su učenici u svakodnevnom kontaktu. Upravo se u ovoj složenoj ulozi nastavnika ogleda značaj i potreba za identifikovanjem njihovih stavova o izbornom programu Obrazovanje za održivi razvoj.

\section{Obrazovanje kao preduslov održivog razvoja}

Značenje pojma održivi razvoj zavisi od toga u kom kontekstu i od strane koga se koristi, od polazišta onih koji ga koriste, a naročito od njihovih interesa i vrednosti (Rončević i Rafajac, 2012), što znači da ne postoji jedinstvena definicija održivog razvoja. Ipak, najrasprostranjenija definicija održivog razvoja je ona kojom se održivi razvoj određuje kao razvoj kojim se zadovoljavaju potrebe sadašnjice bez ugrožavanja mogućnosti budućih generacija da $\mathrm{i}$ one zadovolje svoje potrebe (WCED, 1987).

U priručniku „Education for sustainable development sourcebook” (UNESCO, 2012) održivost se definiše kao paradigma za razmišljanje o budućnosti u kojoj se pitanja razvoja i poboljšanja kvaliteta života temelje na uravnoteženom razmatranju životne sredine, društva i ekonomije. Životna sredina, društvo i ekonomija su tzv. stubovi održivog razvoja, odnosno osnovne dimenzije na kojima je koncept održivog razvoja utemeljen. Ostvarivanje održivog razvoja u ovim dimenzijama se temelji na: sigurnosti, stabilnosti, zdravlju, solidarnosti itd. (društvena komponenta); efikasnoj upotrebi resursa, pravednoj podeli materijalnih dobara, mogućnosti zaposlenja itd. (ekonomska komponenta); očuvanju prirodnih resursa, održivom iskorišćavanju zemljišta, pravovremenom i delotvornom rešavanju problema itd. (ekološka komponenta) (Vrbanec, Garašić i Pašalić, 2011).

Kako piše Nikolić (2012), koncept održivog razvoja podrazumeva „uvažavanje međusobne povezanosti i uslovljenosti ekonomskog, tehnološkog, socijalnog i kulturnog razvoja i stavljanje zaštite životne sredine i kvaliteta života u središte razvojnih aktivnosti” (str. 63). Reč je o konceptu koji kreira ciljeve koji će usmeravati budući razvoj. Traganje za tim ciljevima neizostavno je od obrazovanja (ibid.) koje je značajno razumeti kao neprekidan proces učenja koji nema isključive ciljeve, već se prilagođava stalnim promenama u svetu koje će se neminovno pojavljivati u budućnosti (Čabrilo, Sudari Vasiljević, 2013). Obrazovanje, samim tim, predstavlja osnovni preduslov za ostvarivanje održivog razvoja (Nikolić, 2012). Značajna uloga obrazovanja u oblasti održivog razvoja ogleda se u tome što obrazovanje podstiče promišljanje i izbore koji idu u prilog održivom razvoju; putem obrazovanja se može delovati na način razmišljanja ljudi, na razvoj kritičkog mišljenja, podizanje svesti (Čabrilo i sar., 2013), oblikovanje znanja, veština, vrednosti i stavova usmerenih ka održivom razvoju, a koji su u 
osnovi odgovornog građanstva. Osim toga, obrazovanje samo po sebi determiniše društvene i ekonomske promene i osnova je za postizanje mira, tolerancije i održivosti (Osman, Ladhani, Findlater, \& McKay, 2017).

Sve veća popularnost koncepta održivog razvoja je dovela do toga da se stvore nove forme obrazovanja kao što su „obrazovanje za održivost” i „obrazovanje za održivu budućnost” (Kopnina, 2014). Na međunarodnom nivou i u okviru dokumenata UN najčešće se koristi termin „obrazovanje za održivi razvoj” (Nikolić, 2012). Obrazovanje za održivi razvoj se obično razume kao obrazovanje koje podržava promene u znanjima, veštinama, vrednostima i stavovima sa ciljem stvaranja održivijeg i pravednog društva za sve (Leicht, Heiss, \& Byun, 2018). Nastalo je sjedinjavanjem tema koje se odnose na obrazovanje za zaštitu životne sredine, globalno građanstvo i razvoj. Prvenstveno je bilo usmereno na probleme životne sredine, kao što su klimatske promene i gubitak biodiverziteta, da bi se kasnije proširilo na probleme održivog razvoja, poput smanjenja siromaštva i rodne ravnopravnosti (Joyce, 2018). Reč je o holističkom i transformativnom obrazovanju koje se dotiče sadržaja i ishoda, pedagogije i okruženja za učenje. Pored toga što se prioritet daje uključivanju sadržaja o klimatskim promenama, siromaštvu i održivoj potrošnji u kurikulume, obrazovanje za održivi razvoj usmereno je i na stvaranje interaktivnog okruženja za učenje i nastavu u čijem je fokusu sam učenik. U osnovi, obrazovanje za održivi razvoj zahteva preorijentaciju sa poučavanja na učenje orijentisano na akciju koje karakterišu elementi kao što su: samousmereno učenje, participacija i saradnja, problemska orijentacija, interdisciplinarnost i transdicsiplinarnost, te povezivanje formalnog i neformalnog učenja. Ovakvi pedagoški pristupi su neophodni za razvoj kompetencija bitnih za promovisanje održivog razvoja (Rieckmann, 2018).

Obrazovanje za održivi razvoj je na međunarodnom nivou prepoznato kao ključni faktor održivog razvoja. Uloga obrazovanja za održivi razvoj je istaknuta u okviru tri velike konferencije Ujedinjenih nacija koje su posvećene održivom razvoju: Konferencija UN o životnoj sredini i razvoju (Rio de Žaneiro, 1992. godine); Svetski samit o održivom razvoju (Johanesburg, 2002. godine); Konferencija UN o održivom razvoju (Rio de Žaneiro, 2012. godine) (Leicht et al., 2018). Na Konferenciji UN o životnoj sredini i razvoju iz 1992. godine usvojen je dokument Agenda 21, čime je inicirano uvođenje održivog razvoja i obrazovanja za održivi razvoj u školske kurikulume širom sveta (Kopnina, 2014). U posebnom poglavlju Agende 21 (poglavlje 36: „Unapređivanje obrazovanja, obuke i društvene svesti”), između ostalog, razmatrana su pitanja preorijentacije obrazovanja ka održivom razvoju, pri čemu jedan od ciljeva zahteva da koncept životne sredine i razvoja postane sastavni deo svih programa obrazovanja. U skladu sa time, pred vlade je postavljen zahtev da pripreme strategije sa ciljem integrisanja životne sredine i razvoja, kao i da taj pristup ugrade u obrazovanje na svim nivoima (UN, 1992). Tako je održivi razvoj dobio zasluženo mesto u kurikulumu, kao neizostavan deo savremenog obrazovanja, kroz integraciju sadržaja o održivom razvoju u već postojeće predmete ili kreiranjem posebnih predmeta čiji su sadržaji u potpunosti fokusirani na održivi razvoj.

\section{Održivi razvoj kao sastavni deo kurikuluma}

Značaj integrisanja obrazovanja za održivi razvoj u kurikulume je na međunarodnom nivou, pored Agende 21, prepoznat i u okviru drugih značajnih dokumenata.

Strategija obrazovanja za održivi razvoj, usvojena 2005. godine u Vilniusu sa ciljem osnaživanja zemalja u procesu integracije obrazovanja za održivi razvoj u obrazovne sisteme, predviđa dva načina integracije obrazovanja za održivi razvoj: kroz sve relevantne predmete, ali i kroz 
posebne programe i kurseve iz ove oblasti (UNECE, 2005). Strategija je služila kao osnova za uspešnu implementaciju Dekade obrazovanja za održivi razvoj (Nikolić, 2012), uspostavljene za period od 2005. do 2014. godine, čiji je cilj usmeren na integraciju principa, vrednosti i praksi održivog razvoja u sve aspekte obrazovanja i učenja (Firth \& Smith, 2013). Dekada prepoznaje značaj integracije održivog razvoja u nastavni proces i nastoji da ostvari uticaj na vlade kako bi došlo do neophodnih promena u kurikulumima različitih oblasti, ali i kako bi se osvestila potreba za obukom nastavnika na polju održivog razvoja (Mulà \& Tilbury, 2009).

U Izveštaju sa regionalnog sastanka UNECE-a (Report of the UNECE Regional Ministerial Meeting for the World Summit on Sustainable Development), održanog 2001. godine u Ženevi, pred Svetski samit o održivom razvoju, jedna od odluka je rad na poboljšanju obrazovnih sistema i kreiranje obrazovnih programa o održivom razvoju kako bi se unapredilo razumevanje načina praktične implementacije i promocije održivog razvoja, pri čemu bi posebnu pažnju trebalo posvetiti kurikulumima koji se odnose na održivi razvoj (ECE, 2001). U skladu sa time, u Izveštaju sa Svetskog samita o održivom razvoju (održan 2002. godine u Johanesburgu) naglašena je potreba za ,integracijom održivog razvoja u obrazovne sisteme na svim nivoima sa ciljem promocije obrazovanja kao ključnog agenta promene" (UN, 2002: 61).

Izveštaj sa Konferencije UN o održivom razvoju (održana 2012. godine u Rio de Žaneiru), takođe ukazuje na potrebu za unapređivanjem kapaciteta obrazovnih sistema kako bi pripremili ljude za ostvarivanje održivog razvoja. Jedan od načina za ostvarivanje navedenog je upravo kroz razvoj kurikuluma koji uključuju održivost (UN, 2012).

U Izveštaju sa Svetske konferencije o obrazovanju za održivi razvoj, održane 2014. godine u Japanu (Aichi-Nagoya), navodi se kako bi promene u kurikulumu trebalo da budu praćene promenama u obrazovanju nastavnika i adekvatnim materijalima za učenje uz primenu takvih pristupa kojima se obrazovanje za održivi razvoj posmatra kao sastavni deo svih predmeta, disciplina, vrsta i nivoa obrazovanja i usavršavanja u kontekstu celoživotnog učenja (UNESCO, 2014).

Pored toga, o održivom razvoju u kontekstu kurikuluma govore i mnogi autori. Osman sa saradnicima (Osman et al., 2017) naglašava kako je relevantni kurikulum onaj koji učenicima omogućava da istražuju, analiziraju i „povežu se” sa životnom sredinom i okruženjem, razvijajući pritom znanja i veštine na osnovu kojih će razumeti i rešavati složene probleme sa kojima se životna sredina i društvo suočavaju, kako danas, tako i u budućnosti.

Preorijentacija kurikuluma ka održivom razvoju od obrazovnih zajednica zahteva da prepoznaju znanja, probleme, perspektive, veštine i vrednosti ključne za održivi razvoj u svakoj od dimenzija - zaštita životne sredine, društvo, ekonomija, i da ih integrišu u kurikulum. Pored toga, od njih se zahteva da donesu odluku koji će od mnogobrojnih problema održivog razvoja (npr. biodiverzitet, klimatske promene, jednakost, siromaštvo) postati deo kurikuluma. Prilikom toga, važno je uzeti u obzir specifičnosti lokalne sredine, međutim, vlade često „prepisuju” kurikulume drugih zemalja i regiona, čime se zanemaruju nacionalni ciljevi održivog razvoja i lokalni kontekst (UNESCO, 2012). Važno je istaći i to da postojeći kurikulumi već sadrže mnoge teme koje su svojstvene obrazovanju za održivi razvoj, ali koje nisu identifikovane kao takve: ne prepoznaje se njihov doprinos širem konceptu održivosti (McKeown, 2002).

Integracija održivog razvoja u kurikulum može biti horizontalna - uključivanje održivog razvoja u sadržaje postojećih predmeta, i vertikalna - organizovanje posebnih kurseva posvećenih 
održivom razvoju (Ceulemans \& De Prins, 2010). Još jedan vid integracije održivog razvoja u obrazovni sistem je pristup koji se temelji na tome da čitava institucija, odnosno škola prihvati održivi razvoj kao okvir delovanja i funkcionisanja. To obično podrazumeva prožimanje celokupnog kurikuluma održivim razvojem, smanjenje ekološkog otiska škole, jačanje učešća učenika u aktivnostima posvećenim održivom razvoju i poboljšanje odnosa između škole i zajednice u svim pitanjima koja se odnose na obrazovanje za održivi razvoj (Benavot, 2014).

Obično su u osnovnom obrazovanju teme održivog razvoja povezane sa sadržajima određenog predmeta, ali kada je reč o sekundarnom (srednjem) obrazovanju, postavlja se zahtev za njihovom integracijom u kurikulum na način koji podrazumeva povezivanje sadržaja različitih predmeta pri čemu je naglasak na povećavanju kognitivnog spektra, složenosti zahteva, kritičke svesti, samopouzdanja, osećaja odgovornosti, emocionalne posvećenosti i delokruga delovanja učenika (Geisz \& Schmitt, 2016).

Onda kada se obrazovanje za održivi razvoj razume usko - kao obrazovanje koje se odnosi na zaštitu životne sredine ili na klimatske promene, sadržaji o održivom razvoju su sastavni deo prirodnih nauka, geografije ili društvenih nauka ili postoji obrazovanje za zaštitu životne sredine kao poseban predmet. Šira shvatanja održivog razvoja podrazumevaju i šire sadržaje. Reč je o sadržajima koji se tiču ekonomske, socijalne i kulturne dimenzije i koji se mogu naći u obaveznim/izbornim predmetima kao npr. građansko obrazovanje, moralno obrazovanje, obrazovanje za mir, za ljudska prava i dr. (Benavot, 2014).

Neophodnost za integracijom održivog razvoja u kurikulume prepoznata je i u nacionalnim dokumentima Republike Srbije. U okviru Nacionalne strategije održivog razvoja ističe se potreba za korenitim reformama procesa obrazovanja, te obrazovanje o održivom razvoju u užem smislu kao preduslov za održivi razvoj. S tim u vezi, važno je raditi na integraciji znanja iz relevantnih sektora (životna sredina, društvo, ekonomija), a posebno na njihovoj praktičnoj primeni čime se radi na ostvarivanju kvalitetnijeg života građana. Integraciju sadržaja održivog razvoja neophodno je ostvariti u svim relevantnim predmetima, kao i u neformalnim vidovima obrazovanja (,Službeni glasnik RS”, 57/08).

U Nacionalnoj strategiji za mlade iz 2009. godine naglašena je potreba za integracijom predmeta koji se tiču zaštite životne sredine i razvoja, kao dopuna postojećih nastavnih planova i programa, te potreba pripreme nastavnog kadra za rad u ovoj oblasti (Vlada RS, 2009). Kao nastavak toga, u Nacionalnoj strategiji za mlade za period od 2015. do 2025. godine („Službeni glasnik RS”, 22/15) istaknuto je kako mladi nemaju dovoljno znanja, ni razvijenu svest o životnoj sredini $\mathrm{i}$ održivom razvoju, te da je u vezi s tim potrebno unapređivati obrazovne programe i informisanje mladih, ali i roditelja i nastavnika u oblasti zaštite životne sredine, održivog razvoja i klimatskih promena.

Strategija razvoja obrazovanja do 2020. godine ukazuje na to da obrazovni sistem Republike Srbije ima zadatak da „obrazuje stanovništvo Republike Srbije u skladu sa iskazanim ili prepoznatim razvojnim opredeljenjima u pravcu održivosti i da odgovori na obrazovne potrebe svakog stanovnika Republike Srbije tokom celog njegovog života” („Službeni glasnik RS", 107/12, str. 13).

Analiza programa osnovnog i srednjeg obrazovanja u Republici Srbiji je pokazala da se učenici sa održivim razvojem, i uže, sa zaštitom životne sredine, susreću u okviru različitih predmeta. U osnovnoj školi, to su: Svet oko nas, Priroda i društvo, Građansko vaspitanje, Geografija, 
Biologija, Tehnika i tehnologija, Fizika i Hemija („Službeni glasnik RS”, 10/17;16/18; 5/19; 11/19; 15/18). U srednjim stručnim školama izučava se predmet Ekologija i zaštita životne sredine, a u zavisnosti od područja obrazovanja, postoje i posebni predmeti posvećeni održivom razvoju. To su Održivi razvoj u građevinarstvu (geodezija i građevinarstvo), Održiv razvoj Republike Srbije (ekonomija, pravo i administracija), Održivi razvoj (hemija, nemetali i grafičarstvo), Energetska efikasnost i održivi razvoj (geologija, rudarstvo i metalurgija), Održivi dizajn (šumarstvo i obrada drveta) („Službeni glasnik RS”, 7/18; 15/15; 12/15; 5/17;6/15). Kada je reč o gimnazijama, pojedinim aspektima održivog razvoja dotiču se Biologija, Hemija i Geografija. Pored toga, nova kurikularna koncepcija gimnazijskog obrazovanja obuhvata niz izbornih programa uključujući i Obrazovanje za održivi razvoj (Ministarstvo prosvete, nauke i tehnološkog razvoja RS, 2018). Ciljevi, sadržaji i način realizacije izbornog programa Obrazovanje za održivi razvoj predstavljeni su u nastavku.

\section{Izborni program „Obrazovanje za održivi razvoj”}

Cilj izbornog programa Obrazovanje za održivi razvoj jeste „,da učenik na osnovu istraživanja međuzavisnosti ljudskih aktivnosti i neposrednog okruženja razvije kritički, aktivan i odgovoran odnos prema sebi i okruženju u kom živi i da sadašnjost sagledava i kroz perspektivu budućnosti” („Službeni glasnik RS”, 12/18, str. 231), pri čemu se predviđa da će učenik razviti sposobnost preispitivanja potreba ljudi u kontekstu održivog razvoja i sposobnost kritičkog sagledavanja aktivnosti čoveka u odnosu na njegovo okruženje, prepoznajući pritom pozitivne i negativne primere i posledice neodgovornog ponašanja prema okruženju, kao i da će raditi na smanjivanju ličnog negativnog delovanja, te aktivno učestvovati u aktivnostima usmerenim na unapređivanju kvaliteta života u okruženju („Službeni glasnik RS”, 12/18; 8/19).

U Pravilniku o Programu nastave i učenja za prvi razred gimnazije („Službeni glasnik RS”, 12/18) predstavljene su tri obavezne teme koje čine okosnicu početka izučavanja izbornog programa Obrazovanje za održivi razvoj, odnosno početak izučavanja komponenata životne sredine. To su: Voda, Vazduh i Održivi gradovi i naselja. Za svaku od njih istaknuti su očekivani ishodi i sadržaji koji nastavniku služe kao smernice, ali koje može dopuniti. Učenici imaju zadatak da odaberu temu koju će istraživati kroz grupni rad, uz pomoć nastavnika koji ih usmerava u procesu prikupljanja podataka (odabir izvora i tehnika, obilazak okruženja, posete institucijama i dr.). Nakon što učenici završe svoje istraživanje i predstave rezultate ostalim učenicima, organizuje se diskusija sa ciljem odabira problema istraživačkog projekta. Svrha projekta je proizvod kao npr. informacije o načinima štednje vode, film o divljim deponijama, predstava o obeležavanju Dana zaštite voda, dopis gradonačelniku za pronalaženje mesta za odlaganje elektronskog otpada itd. Rezultate projekta značajno je predstaviti drugim učenicima, školi, roditeljima, ali i lokalnoj zajednici i medijima, dok je zadatak škole da postane primer dobre prakse, tako što će, vodeći se tim rezultatima, implementirati principe održivog razvoja u svoj rad i funkionisanje (ibid.).

U Programu nastave i učenja za drugi razred gimnazije („Službeni glasnik RS”, 8/19) su takođe predstavljene tri obavezne teme: Održivo upravljanje zemljištem; Proizvodnja, distribucija i potrošnja hrane kao činilac održivog razvoja i Upravljanje otpadom. Za svaku temu date su opšte međupredmetne kompetencije, očekivani ishodi i ključni pojmovi, odnosno sadržaji. Istaknuto je kako teme pružaju mogućnost za primenu integrativnog pristupa, eksperimenta, simulacije procesa, metode diskusije (debate), edukativnih radionica i projektne nastave i dati su primeri projektnih zadataka za praktičnu realizaciju. Nastavnik upoznaje učenike sa temama i sadržajima, podstiče njihovo interesovanje za proučavanje i angažovani pristup u rešavanju 
problema održivog razvoja, negovanje ispravnih vrednosti i navika, te kontinuirano prati i vrednuje razvoj kritičkog i kreativnog mišljenja, nivo znanja, sposobnosti i veštine, nivo sprovođenja aktivnosti i razvoj vaspitnih komponenata kao što su uverenja, stavovi, ponašanje odgovornost i dr. Predviđa se mogućnost grupnog rada, ali i rad u parovima za praktičnu realizaciju istraživačkih aktivnosti koje za cilj imaju dolaženje do saznanja o mogućnostima smanjivanja ili rešavanja proučavanog problema. I u ovom slučaju naglasak je na širenju rezultata istraživanja (ibid.).

U Tabeli 1 je dat pregled osnovnih tema, pojmova i sadržaja sa kojima se učenici susreću u okviru izbornog programa Obrazovanje za održivi razvoj u prvom i drugom razredu gimnazije.

Tabela 1. Izborni program Obrazovanje za održivi razvoj: pregled tema, pojmova i sadržaja

\begin{tabular}{cl}
\hline TEMA & \multicolumn{1}{c}{ POJMOVI/SADRŽAJ } \\
\hline VODA & $\begin{array}{l}\text { kvalitet voda u okruženju; voda za piće; izvori zagađivanja vode } \\
\text { (deponije, poljoprivreda, industrija, domaćinstvo) i dr. }\end{array}$ \\
\hline VAZDUH & $\begin{array}{l}\text { obnovljivi i neobnovljivi izvori energije i zagađivanje vazduha, } \\
\text { indikatori narušenog kvaliteta vazduha i mogućnosti za njegovo } \\
\text { poboljšanje i dr. }\end{array}$ \\
\hline ODRŽIVI GRADOVI I NASELJA & $\begin{array}{l}\text { održivi gradovi i naselja u svetu, kvalitet života nekad i sad; } \\
\text { održivost kuća i zgrada, mogućnosti održive škole i dr. }\end{array}$ \\
\hline ODRŽIVO UPRAVLJANJE & $\begin{array}{l}\text { održivo upravljanje zemljištem; zagađivanje i degradacija zemljišta; } \\
\text { praćenje kvaliteta i zaštita zemljišta i dr. }\end{array}$ \\
\hline ZROMLJIŠTEM & $\begin{array}{l}\text { lokalna održiva poljoprivreda; kvalitet namirnica, navike u ishrani i } \\
\text { bezbednost hrane; GMO; ekološki otisak i dr. }\end{array}$ \\
\hline ČINILAC ODRŽIVOG RAZVOJA & održivo upravljanje otpadom; odlaganje otpada; reciklaža; \\
\hline UPRAVLJANJE OTPADOM & odgovorna kupovina; cirkularna ekonomija i otpad i dr.
\end{tabular}

(prema: „Službeni glasnik RS”, 12/18; 8/19)

Na osnovu datog prikaza može se zaključiti da je izborni program Obrazovanje za održivi razvoj fokusiran na teme donekle bliske učenicima, teme iz svakodnevnog okruženja, sa kojima učenici danas ili u budućnosti mogu doći u dodir, koje in se tiču i o kojima bi valjalo promišljati, kako bi njihovi izbori danas bili vođeni globalnom perspektivom i budućim posledicama.

\section{Metodologija istraživanja}

Istraživanje je zamišljeno kao pilot, probno istraživanje kako bi se formirala početna slika o stavovima nastavnika gimnazija u vezi sa izbornim programom Obrazovanje za održivi razvoj, te stekla osnovna saznanja koja će poslužiti kao smernice za buduća, dublja, proučavanja ove problematike.

Cilj istraživanja je ispitati stavove nastavnika gimnazija u vezi sa izbornim programom Obrazovanje za održivi razvoj. Osnovna pretpostavka je da nastavnici nemaju razvijenu svest o potrebi i značaju datog izbornog programa, kao i da ovaj program posmatraju kao dodatno opterećenje za nastavni plan i program. Istraživanje je utemeljeno na deskriptivnoj metodi i tehnici skaliranja. Instrument, koji se sastoji od 10 tvrdnji kojima se ispituju percepcije nastavnika prema izbornom programu Obrazovanje za održivi razvoj, posebno je pripremljen za potrebe istraživanja (tvrdnje su date u Tabeli 3).

U istraživanju je učestvovalo 173 nastavnika, i to: 26 nastavnika iz Gimnazije „Prokuplje” (15\%), 13 nastavnika iz „Knjaževačke gimnazije” (7,5\%), 5 nastavnika iz Gimnazije „Bora Stanković” u 
Boru (2,9\%) i 129 nastavnika iz gimnazija „Bora Stanković”, „Stevan Sremac”, „9. maj” i „Svetozar Marković” u Nišu (74,6\%). Uzorak ispitanika je prigodan, sastavljen od onih nastavnika koji su u trenutku sprovođenja istraživanja istraživaču bili na raspolaganju. Struktura ispitanika, s obzirom na postavljene varijable, predstavljena je u Tabeli 2.

Tabela 2. Struktura uzorka

\begin{tabular}{|c|c|c|c|c|c|}
\hline & & $\mathrm{N}$ & kumulativni \% & Nedostaje & Ukupno \\
\hline \multirow{4}{*}{ Dužina radnog staža } & do 5 god. & 28 & 16.6 & \multirow{4}{*}{4} & \multirow{4}{*}{173} \\
\hline & 6-15 god. & 54 & 32.0 & & \\
\hline & 16-25 god. & 61 & 36.1 & & \\
\hline & preko 25 god. & 26 & 15.4 & & \\
\hline \multirow{2}{*}{$\begin{array}{l}\text { Da li se stručno } \\
\text { usavršavate u oblasti } \\
\text { održivog razvoja? }\end{array}$} & $\mathrm{da}$ & 31 & 20.5 & \multirow{2}{*}{22} & \multirow{2}{*}{173} \\
\hline & ne & 120 & 79.5 & & \\
\hline \multirow{2}{*}{$\begin{array}{l}\text { Da li se u Vašoj školi } \\
\text { realizuje izborni program } \\
\text { Obrazovanje za održivi } \\
\text { razvoj? }\end{array}$} & da & 64 & 37 & \multirow{2}{*}{-} & \multirow{2}{*}{173} \\
\hline & ne & 109 & 63 & & \\
\hline
\end{tabular}

Dobijeni podaci su obrađeni u statističkom programu SPSS, pri čemu je korišćena deskriptivna statistika (frekvencije i procenti), F-test (za nezavisnu varijablu dužina radnog staža), kao i ttest (za nezavisne varijable stručno usavršavanje u oblasti održivog razvoja i realizacija izbornog programa Obrazovanje za održivi razvoj). Odgovori ispitanika su sa petostepene skale (uopšte se ne slažem, ne slažem se, niti se slažem, niti se ne slažem, slažem se, potpuno se slažem) sažeti u tri kategorije: ne slažem se (uopšte se ne slažem i ne slažem se), neodlučan/a sam (niti se slažem, niti se ne slažem) i slažem se (slažem se i u potpunosti se slažem).

U trenutku sprovođenja istraživanja (maj/jun 2019. godine), izborni program Obrazovanje za održivi razvoj je realizovan u gimnazijama „9. maj” i „Svetozar Marković” u Nišu.

\section{Rezultati i diskusija}

Stavovi nastavnika o izbornom programu Obrazovanje za održivi razvoj (frekvencije i procenti), zajedno sa tvrdnjama na kojima je istraživanje utemeljeno, predstavljeni su u Tabeli 3.

Tabela 3. Stavovi nastavnika o izbornom programu Obrazovanje za održivi razvoj

\begin{tabular}{|c|c|c|c|c|c|c|c|c|}
\hline \multirow{2}{*}{ Tvrdnje } & \multicolumn{2}{|c|}{ Ne slažem se } & \multicolumn{2}{|c|}{$\begin{array}{l}\text { Neodlučan/a } \\
\text { sam }\end{array}$} & \multicolumn{2}{|c|}{ Slažem se } & \multirow{2}{*}{$\begin{array}{c}\text { Nedostaje } \\
\mathrm{N}\end{array}$} & \multirow{2}{*}{$\begin{array}{c}\text { Ukupno } \\
\text { N }\end{array}$} \\
\hline & $\mathrm{N}$ & $\begin{array}{c}\text { validni } \\
\%\end{array}$ & $\mathrm{~N}$ & $\begin{array}{c}\text { validni } \\
\%\end{array}$ & $\mathrm{~N}$ & $\begin{array}{c}\text { validni } \\
\%\end{array}$ & & \\
\hline $\begin{array}{l}\text { Izborni program } \\
\text { Obrazovanje za održivi } \\
\text { razvoj je samo dodatno } \\
\text { opterećenje za nastavni } \\
\text { plan i program }\end{array}$ & 45 & 26.2 & 65 & 37.8 & 62 & 36 & 1 & 173 \\
\hline
\end{tabular}




\begin{tabular}{|c|c|c|c|c|c|c|c|}
\hline $\begin{array}{l}\text { Izbornim programom } \\
\text { Obrazovanje za održivi } \\
\text { razvoj ne može se delovati } \\
\text { na svest i održivo } \\
\text { ponašanje učenika }\end{array}$ & 85 & 49.1 & 44 & 25.4 & 44 & 25.4 & - \\
\hline $\begin{array}{l}\text { Obrazovanje za održivi } \\
\text { razvoj bi trebalo da bude } \\
\text { obavezan predmet }\end{array}$ & 91 & 52.9 & 51 & 29.7 & 30 & 17.4 & 1 \\
\hline $\begin{array}{l}\text { Predmet Obrazovanje za } \\
\text { održivi razvoj bi trebalo da } \\
\text { se izučava u osnovnoj } \\
\text { školi }\end{array}$ & 57 & 33.1 & 46 & 26.7 & 69 & 40.2 & 1 \\
\hline $\begin{array}{l}\text { Imam dovoljno znanja i } \\
\text { veštine da bih mogao/la } \\
\text { da predajem izborni } \\
\text { program Obrazovanje za } \\
\text { održivi razvoj }\end{array}$ & 71 & 41 & 58 & 33.5 & 44 & 25.5 & - \\
\hline $\begin{array}{l}\text { Za realizaciju izbornog } \\
\text { programa Obrazovanje za } \\
\text { održivi razvoj potrebni su } \\
\text { posebno obučeni } \\
\text { nastavnici }\end{array}$ & 26 & 15 & 53 & 30.6 & 94 & 54.3 & - \\
\hline $\begin{array}{l}\text { Učenici pokazuju } \\
\text { zainteresovanost za } \\
\text { pohađanje izbornog } \\
\text { programa Obrazovanje za } \\
\text { održivi razvoj }\end{array}$ & 58 & 33.7 & 81 & 47.1 & 33 & 19.1 & 1 \\
\hline $\begin{array}{l}\text { Otkad je uveden izborni } \\
\text { program Obrazovanje za } \\
\text { održivi razvoj prestao/la } \\
\text { sam da u predmet koji } \\
\text { predajem unosim sadržaje } \\
\text { iz oblasti održivog razvoja }\end{array}$ & 87 & 51.2 & 61 & 35.9 & 22 & 12.9 & 3 \\
\hline $\begin{array}{l}\text { Obrazovanje za održivi } \\
\text { razvoj bi trebalo ukloniti } \\
\text { sa liste izbornih programa }\end{array}$ & 73 & 42.4 & 65 & 37.8 & 34 & 18.7 & 1 \\
\hline $\begin{array}{l}\text { Realizacija izbornog } \\
\text { programa Obrazovanje za } \\
\text { održivi razvoj za mene bi } \\
\text { predstavljala samo } \\
\text { dodatno opterećenje }\end{array}$ & 58 & 33.5 & 60 & 34.7 & 55 & 31.8 & - \\
\hline
\end{tabular}

Ne može se izvesti jasan zaključak o jedinstvenom stavu nastavnika prema tvrdnji Izborni program Obrazovanje za održivi razvoj je samo dodatno opterećenje za nastavni plan i program s obzirom na to da ima nastavnika koji smatraju da predmet nije dodatno opterećenje za nastavni plan i program $(26,2 \%)$ i koji, može se reći, uviđaju značaj i neophodnost bavljenja ovom problematikom; onih koji smatraju da predmet jeste dodatno opterećenje (36\%), i onih koji su neodlučni (37,8\%).

Skoro polovina ispitanika (49,1\%) pokazuje poverenje u ishode izbornog programa Obrazovanje za održivi razvoj, odnosno smatraju da se putem ovog programa može uticati na svest $\mathrm{i}$ ponašanje učenika u oblasti održivog razvoja. Ipak, isti procenat nastavnika $(25,4 \%)$ pokazuje neodlučnost i izražava negativan stav $(25,4 \%)$ u vezi sa navedenim. Uzrok tome može biti to što nastavnicima problematika održivog razvoja nije dovoljno poznata, kao ni sam izborni 
program, sadržaji koji su propisani, te način njihove praktične realizacije, odnosno odgovor može zavisiti od predmeta koji nastavnik predaje i upućenosti u održivi razvoj (nastavnicima hemije, biologije, fizike i geografije je održivi razvoj „bliži” jer sadržaji ovih predmeta obuhvataju neke aspekte održivog razvoja).

Najveći procenat nastavnika, tek nešto više od polovine $(52,4 \%)$ smatra da Obrazovanje za održivi razvoj ne bi trebalo da bude obavezan predmet, što može da sugeriše kako nastavnici smatraju da su problemi održivog razvoja u dovoljnoj meri zastupljeni u školskom kurikulumu, ili čak da ne uviđaju značaj uključivanja ove problematike u nastavne sadržaje.

Polazeći od činjenice da je obrazovanje za održivi razvoj proces koji počinje u ranom detinjstvu, i traje tokom čitavog života (UNECE, 2005), očekivano je da se nastavnici slože sa tvrdnjom Predmet Obrazovanje za održivi razvoj bi trebalo da se izučava u osnovnoj školi. Ipak, stavovi nastavnika su podeljeni: ne slaže se $33,1 \%$, neodlučnih je $26,7 \%$, a slaže se $40,2 \%$. Moguće je da nastavnici gimnazija nisu upoznati sa time na koji način i u kolikoj meri se posvećuje pažnja obrazovanju učenika za održivi razvoj na nižim nivoima obrazovanja, u osnovnoj školi i predškolskom obrazovanju, te da neki nastavnici smatraju da je održivi razvoj zastupljen u dovoljnoj meri, dok drugi ne uviđaju značaj i potrebu da se sa obrazovanjem za održivi razvoj počne što pre. Ipak, iako nastavnici ne pokazuju jedinstven stav, najveći procenat $(40,2 \%)$ smatra da bi predmet posvećen održivom razvoju trebalo da se izučava u osnovnoj školi.

Podeljenost u stavovima nastavnika prisutna je i kod tvrdnje Imam dovoljno znanja i veštine da bih mogao/la da predajem izborni program Obrazovanje za održivi razvoj: 41\% nastavnika se ne slaže, $33,5 \%$ je neodlučno, a $25,5 \%$ se slaže. I u ovom slučaju se uzrok može tražiti u predmetu koji nastavnik predaje, ali odgovori nastavnika takođe mogu zavisiti i od stručnog usavršavanja, koje u oblasti održivog razvoja izostaje (Tabela 2).

Više od polovine ispitanika (54,3\%) smatra da su za realizaciju izbornog programa Obrazovanje za održivi razvoj potrebni posebno obučeni nastavnici, što ukazuje na to da ovi nastavnici imaju razvijenu svest o tome da je kvalitetno obrazovanje nastavnika preduslov kvalitetnog obrazovanja učenika. Pored toga, važno je ukazati na mogućnost da je negativan stav nastavnika (15\%) u vezi sa navedenim uslovljen time što nastavnici hemije, biologije, geografije ili fizike mogu predavati ovaj predmet („Službeni glasnik RS”, 13/18), bez obzira na stručno usavršavanje.

Negativan stav (33,7\%) i neodlučnost $(47,1 \%)$ u vezi sa tvrdnjom Učenici pokazuju zainteresovanost za pohađanje predmeta Obrazovanje za održivi razvoj verovatno su rezultat toga što anketirani nastavnici rade u gimnaziji u kojoj ovaj izborni predmet nije odabran, te samim tim, nemaju pravi uvid u zainteresovanost učenika za ovu problematiku, ali takođe vrlo je verovatno da se upravo zbog nedovoljne zainteresovanosti učenika predmet ne realizuje.

lako tek nešto više od polovine, najveći procenat nastavnika $(51,2 \%)$ je na tvrdnju Otkad je uveden izborni predmet Obrazovanje za održivi razvoj prestao/la sam da u predmet koji predajem unosim sadržaje iz oblasti održivog razvoja odgovorio sa ne slažem se što je ohrabrujući podatak.

Neusaglašenost u stavovima nastavnika prisutna je i kod tvrdnje Obrazovanje za održivi razvoj bi trebalo ukloniti sa liste izbornih programa: odgovor ne slažem se dalo je 42,4\%, neodlučnih je $37,8 \%$, a slaže se $18,7 \%$, što opet može biti uzrokovano predmetom koji predaju, udaljenošću 
sadržaja iz tog predmeta od sadržaja o održivom razvoju, nepoznavanjem koncepta održivog razvoja i sl.

Podeljenost u odgovorima je izražena i u vezi sa tvrdnjom Realizacija izbornog predmeta Obrazovanje za održivi razvoj za mene bi predstavljala samo dodatno opterećenje (odgovor ne slažem se dalo je $33,5 \%$ ispitanika, neodlučnih je $34,7 \%$, a slaže se $31,8 \%$ nastavnika), što zavisi od ličnih obaveza pojedinačnog nastavnika u nastavi i njihove želje i motivacije da se bave nečim novim, težnje ka izazovima i sl.

Statistički značajna razlika u stavovima nastavnika s obzirom na dužinu radnog staža utvrđena je kod tvrdnje Predmet Obrazovanje za održivi razvoj bi trebalo da se izučava u osnovnoj školi $(\mathrm{F}=2.801, \mathrm{df}=3, \mathrm{p}=0.042(\mathrm{p}<.001))$. Kada je reč o ostalim varijablama (realizacija izbornog programa Obrazovanje za održivi razvoj i stručno usavršavanje u oblasti održivog razvoja), statistički značajna razlika u stavovima ispitanika nije utvrđena. Mali broj nastavnika se stručno usavršava u oblasti održivog razvoja (20,5\%), a 22 nastavnika nije dalo odgovor na pitanje Da li se stručno usavršavate u oblasti održivog razvoja? Moguće je da je do toga došlo iz razloga što nastavnici ne žele da priznaju da ne rade na svom obrazovanju i usavršavanju u oblasti održivog razvoja. Sa druge strane, ostaje otvoreno pitanje da li se nastavnici koji su odgovorili potvrdno zaista usavršavaju ili je njihov odgovor društveno poželjan, te da su su odgovorili potvrdno zato što se od njih, kao predstavnika nastavničke profesije, očekuje da kontinuirano rade na svom usavršavanju, posebno kada je reč o aktuelnoj temi kao što je održivi razvoj.

Rasipanje odgovora nastavnika na ponuđene kategorije prisutno je kod većine tvrdnji, na osnovu čega možemo zaključiti da svest nastavnika o potrebi i značaju izbornog programa Obrazovanje za održivi razvoj nije razvijena. Ipak, kako nastavnici nisu pokazali eksplicitno jasan stav u vezi sa time da je izborni program dodatno opterećenje za nastavni plan i program, pretpostavku da nastavnici nemaju razvijenu svest o potrebi i značaju izbornog programa Obrazovanje za održivi razvoj, te da ovaj program posmatraju kao dodatno opterećenje za nastavni plan i program možemo delimično potvrditi.

\section{Zaključak}

Školske 2018/19. godine je u nastavni plan i program gimnazijskog obrazovanja u Srbiji uključeno nekoliko izbornih programa, između ostalog i Obrazovanje za održivi razvoj. S obzirom na to da je održivi razvoj aktuelna tema savremenog društva, kao i da je potreba za njegovom integracijom u kurikulume prepoznata od strane mnogih međunarodnih $i$ nacionalnih dokumenata, istraživanje je fokusirano na pomenuti izborni program, jer je reč o programu čiji su sadržaji u potpunosti posvećeni održivom razvoju. Preciznije, fokus istraživanja je na nastavnicima koji rade u gimnazijama, odnosno na njihovim stavovima u vezi sa izbornim programom Obrazovanje za održivi razvoj. Istraživanje je započeto sa pretpostavkom da nastavnici nemaju razvijenu svest o potrebi i značaju datog izbornog programa, kao i da ovaj program posmatraju kao dodatno opterećenje za nastavni plan i program. Ova pretpostavka je delimično potvrđena, a s obzirom na to da:

- nastavnici ne pokazuju eksplicitno jasan stav u vezi sa time da li izborni program predstavlja dodatno opterećenje za nastavni plan i program;

- nastavnici su podeljenog mišljenja i kada je reč o tome da li bi realizacija ovog izbornog programa predstavljala dodatno opterećenje za njih same, o tome da li poseduju adekvatna znanja i veštine za njegovu realizaciju, kao i o tome da li ovaj program uopšte treba da bude na listi izbornih programa; 
- $\quad$ najveći procenat ispitanih nastavnika smatra da Obrazovanje za održivi razvoj ne bi trebalo da bude obavezan predmet, kao i da su za njegovu realizaciju potrebni posebno obučeni nastavnici, ali i da nisu prestali da u sadržaje predmeta koji predaju unose sadržaje iz oblasti održivog razvoja;

- nastavnici pokazuju neusaglašenost i kada je reč o: mogućnostima da se putem izbornog programa utiče na svest i ponašanje učenika u oblasti održivog razvoja; potrebi da se obrazovanje za održivi razvoj kao predmet izučava u osnovnoj školi i zainteresovanosti učenika za pohađanje izbornog programa.

Generalno se može zaključiti da su stavovi nastavnika o izbornom programu Obrazovanje za održivi razvoj neusaglašeni, što sugeriše na to da nastavnicima problematika održivog razvoja nije bliska, te da korene negativnih i neodlučnih stavova u vezi sa izbornim programom treba tražiti u znanjima i stavovima nastavnika o samom konceptu održivog razvoja. Samim tim, ukoliko nastavnik nije upoznat sa održivim razvojem kao takvim, malo je verovatno da će biti upoznat sa izbornim programom Obrazovanje za održivi razvoj, naročito ukoliko je reč o nastavnicima čiji predmeti imaju malo ili nimalo veze sa održivim razvojem, ili bar ta veza nije jasno prepoznata. Iz tog razloga, preporuka je da se istraže stavovi nastavnika uzimajući pritom predmet koji nastavnik predaje kao varijablu, čime bi se mogle sagledati razlike u stavovima nastavnika o izbornom programu Obrazovanje za održivi razvoj iz perspektive onih nastavnika kojima je ovaj predmet donekle „blizak”, te koji imaju mogućnost da ga praktično realizuju (biologija, hemija, geografija, fizika), i nastavnika drugih predmeta. Pored toga, naglasak se mora staviti i na neophodnost specifične obuke nastavnika koji imaju mogućnost da drže ovaj izborni predmet, ali i na potrebu za izradom udžbenika za rad u okviru izbornog predmeta, koji bi se odnosio isključivo na problematiku održivog razvoja, te pružao minimalna osnovna znanja iz ove oblasti.

Važno je napomenuti i da je usavršavanje nastavnika u oblasti održivog razvoja veoma značajno, ne samo u profesionalnom pogledu, jer kao nastavnici imaju zadatak da rade na obrazovanju učenika za održivi razvoj, već i zbog toga što kao građani savremenog društva moraju biti upoznati sa održivim razvojem i nastojati da deluju održivo u svom svakodnevnom životu.

\section{Literatura:}

Benavot, A. (2014). Education for Sustainable Development in Primary and Secondary Education. Preuzeto https://www.researchgate.net/publication/282342116_Education_for_Sustainable_De velopment_in_Primary_and_Secondary_Education (pristupljeno $31.1 . \quad 2020$ ). doi:10.13140/RG.2.1.1978.9283.

Ceulemans, K., \& De Prins, M. (2010). Teacher's Manual and Method for SD Integration in Curricula. Journal of Cleaner Production, 18, 645-651. doi:10.1016/j.jclepro.2009.09.014.

Čabrilo, N., Sudar, S., i Vasiljević, M. (2013). Mogućnosti implementiranja sadržaja održivog razvoja u obrazovni sistem Crne Gore. Podgorica: Regionalni centar za životnu sredinu za Centralnu i Istočnu Evropu (REC), Kancelarija u Crnoj Gori.

ECE (2001). Report of the UNECE Regional Ministerial Meeting for the World Summit on Sustainable Development. Preuzeto https://www.unece.org/fileadmin/DAM/env/documents/2001/ece/ac22/ece.ac.22.2001 .2.e.pdf (pristupljeno 31. 1. 2020). 
Firth, R., \& Smith, M. (2013). As the UN Decade of Education for Sustainable Development Comes to an End: What Has it Achieved and What Are the Ways Forward?. The Curriculum Journal, 24 (2), 169-180. doi:10.1080/09585176.2013.802893.

Geisz, M., \& Schmitt, M. (2016). School Conditions and Educational Challenges. In: J. R. Schreiber, \& H. Siege (Eds.), Curriculum Framework: Education for Sustainable Development (pp. 57-111). Bonn: Engagement Global gGmbH.

Joyce, A. (2018). How Can Information and Communication Technologies Support Education for Sustainable Development. Preuzeto sa https://www.researchgate.net/publication/326507525_How_Can_Information_and_C ommunication_Technologies_Support_Education_for_Sustainable_Development_ $\bar{A}$ Critique (pristupljeno 12.1. 2020). doi:10.21125/edūlearn.2018.2170.

Kopnina, H. (2014). Revisiting Education for Sustainable Development (ESD): Examining Anthropocentric Bias Through the Transition of Environmental Education to ESD. Sustainable Development, 22, 73-83. doi:10.1002/sd.529.

Leicht, A., Heiss, J., \& Byun W. J. (Eds.) (2018). Issues and Trends in Education for Sustainable Development. Paris, France: UNESCO.

McKeown, R. (2002). Education for sustainable development toolkit. Preuzeto sa http://www.esdtoolkit.org (pristupljeno 31. 1. 2020).

Ministarstvo prosvete, nauke i tehnološkog razvoja Republike Srbije (2018). Izveštaj o realizaciji akcionog plana za sprovođenje strategije razvoja obrazovanja do 2020. godine. Preuzeto sa http://www.mpn.gov.rs/wp-content/uploads/2018/08/AP-SROSIZVESTAJ-15jun.pdf (pristupljeno 31. 2. 2020).

Mulà, I., \& Tilbury, D. (2009). A United Nations Decade of Education for Sustainable Development (2005-14): What Difference will it Make?. Journal of Education for Sustainable Development, 3 (1), 87-97. doi:10.1177/097340820900300116.

Nacionalna strategija održivog razvoja, ,,Službeni glasnik RS”, god. 64, br. 57/08.

Nacionalna strategija za mlade za period od 2015. do 2025. godine, ,,Službeni glasnik RS”, god. 71, br. 22/15.

Nikolić, V. (2012). Teorija i organizacija obrazovanja za zaštitu. Niš: Filozofski fakultet.

Osman, A., Ladhani, S., Findlater, E. and McKay, V. (2017). Curriculum Framework for the Sustainable Development Goals. Commonwealth Secretariat. Preuzeto sa https://www.thecommonwealth-educationhub.net/wp-

content/uploads/2017/01/Curriculum_Framework_for_SDGs_July_2017.pdf

(pristupljeno 31.1. 2020).

Pravilnik o dopunama Pravilnika o stepenu i vrsti obrazovanja nastavnika, stručnih saradnika i pomoćnih nastavnika u gimnaziji, „Službeni glasnik RS”, br. 13/18.

Pravilnik o dopuni pravilnika o nastavnom planu i programu stručnih predmeta srednjeg stručnog obrazovanju u području rada Hemija, nemetali i grafičarstvo, „Službeni glasnik RS”, god. 64 , br.12/15.

Pravilnik o dopuni pravilnika o nastavnom planu i programu stručnih predmeta srednjeg stručnog obrazovanju u području rada Šumarstvo i obrada drveta, , Službeni glasnik RS”, god. 64 , br. 6/15.

Pravilnik o izmeni i dopunama pravilnika o nastavnom planu i programu srednjeg stručnog obrazovanja u području rada Ekonomija, pravo i administracija, „Službeni glasnik RS”, god. 64 , br. $15 / 15$.

Pravilnik o nastavnom planu i programu stručnih predmeta srednjeg stručnog obrazovanju u području rada Geologija, rudarstvo i metalurgija, „Službeni glasnik RS”, god. 66, br. $5 / 17$. 
Pravilnik o planu i programu nastave i učenja stručnih predmeta srednjeg stručnog obrazovanja u području rada Geodezija i građevinarstvo, „Službeni glasnik RS”, god. 67, br. 7/18.

Pravilnik o Planu nastave i učenja za peti i šesti razred osnovnog obrazovanja i vaspitanja i programu nastave i učenja za peti i šesti razred osnovnog obrazovanja i vaspitanja, „Službeni glasnik RS”, god. 67, br. 15/18.

Pravilnik o Planu nastave i učenja za prvi ciklus osnovnog obrazovanja i vaspitanja i programu nastave i učenja za prvi razred osnovnog obrazovanja i vaspitanja, „Službeni glasnik RS", god. 66, br. 10/17.

Pravilnik o Programu nastave i učenja za četvrti razred osnovnog obrazovanja i vaspitanja, „Službeni glasnik RS”, god. 68, br. 11/19.

Pravilnik o Programu nastave i učenja za drugi razred osnovnog obrazovanja i vaspitanja, „Službeni glasnik RS”, god. 67, br. 16/18.

Pravilnik o Programu nastave i učenja za osmi razred osnovnog obrazovanja i vaspitanja, Službeni glasnik RS, god. 68, br. 11/19.

Pravilnik o Programu nastave i učenja za prvi razred gimnazije, „Službeni glasnik RS”, god. 67, br. $12 / 18$.

Pravilnik o Programu nastave i učenja za sedmi razred osnovnog obrazovanja i vaspitanja, „Službeni glasnik RS”, god. 68, br. 5/19.

Pravilnik o Programu nastave i učenja za treći razred osnovnog obrazovanja i vaspitanja, „Službeni glasnik RS”, god. 68, br. 5/19.

Program nastave i učenja za drugi razred gimnazije, „Službeni glasnik RS”, god. 68, br. 8/19.

Rieckmann, M. (2018). Learning to Transform the World: Key Competencies in Education for Sustainable Development. In: A. Leicht, J. Heiss, \& W. J. Byun (Eds.). Issues and Trends in Education for Sustainable Development (pp. 39-59). Paris, France: UNESCO.

Rončević, N., i Rafajac, B. (2012). Održivi razvoj. Izazov za sveučilište?. Rijeka: Filozofski fakultet.

Strategija razvoja obrazovanja u Srbiji do 2020. godine, „Službeni glasnik RS”, god. 68, br. $107 / 12$.

UN (1992). Agenda 21: rezime. Preuzeto sa http://wasteenvironment.vin.bg.ac.rs/docu/agenda_21.pdf (pristupljeno 30. 1. 2020).

UN (2002). United Nations Report of the World Summit on Sustainable Development. Preuzeto sa https://digitallibrary.un.org/record/478154? In=en (pristupljeno 30. 1. 2020).

UN (2012). Report of the United NationsConference on Sustainable Development. Preuzeto sa https://www.un.org/ga/search/view_doc.asp?symbol=A/CONF.216/16\&Lang=E (pristupljeno 30.1.2020).

UNECE (2005). Strategija obrazovanja za održivi razvoj. Preuzeto sa http://www.unece.org/fileadmin/DAM/env/esd/strategytext/StrategyinSebian.pdf (pristupljeno 30. 1. 2020).

UNESCO (2012). Education for Sustainable Development Sourcebook. Paris, France: UNESCO.

UNESCO (2014). UNESCO World Conference on Education for Sustainable Development Conference Report by the General Rapporteur. Preuzeto sa https://unesdoc.unesco.org/ark:/48223/pfooo0232888 (pristupljeno 30. 1. 2020).

Vlada Repubilike Srbije (2009). Nacionalna strategija za mlade. Preuzeto sa https://www.srbija.gov.rs/dokument/45678/strategije.php (pristupljeno 31. 1. 2020).

Vrbanec, B., Garašić, D., \& Pašalić, A. (2011). Obrazovanje za održivi razvoj: Priručnik za osnovne i srednje škole. Zagreb: Agencija za odgoj i obrazovanje.

WCED (1987). Report of the World Comission on Environment and Development: Our Common $\begin{array}{lllll}\text { Future. } & \text { Preuzeto } & 8 . & 1 . & 2020 .\end{array}$ https://sustainabledevelopment.un.org/content/documents/5987our-commonfuture.pdf. 


\section{Biografska beleška}

Tamara Vukić je student treće godine doktorskih akademskih studija na Departmanu za pedagogiju Filozofskog fakulteta u Nišu. Stipendista je Ministarstva prosvete, nauke i tehnološkog razvoja. Trenutno je, kao stipendista, angažovana u nastavi na Fakultetu zaštite na radu u Nišu. Njena interesovanja za naučno-istraživačku delatnost usmerena su ka didaktičkim i metodičkim problemima obrazovanja za održivi razvoj. 